\title{
REVIEW
}

\section{Paralysis as a result of traction for the treatment of scoliosis: a forgotten lesson from history}

\author{
M-F Weiner and JR Silver \\ Stoke Mandeville Hospital, Buckinghamshire, UK
}

\begin{abstract}
Study design: Literature review.
Setting: Europe with special reference to France.

Objectives: To review the treatment of spinal deformity in nineteenth century Europe and explain the high incidence of paralysis as a result of forceful traction of the spinal column to treat scoliosis in France as compared with other European countries.

Conclusion: Although well described in the nineteenth century French medical literature, the dangers of forceful traction on the spinal column to correct spinal deformity were not recognized in Europe or the USA until the halofemoral traction method of treatment was used in the 1970s.

Spinal Cord (2009) 47, 429-434; doi:10.1038/sc.2009.19; published online 7 April 2009
\end{abstract}

Keywords: mechanical traction; spinal column; paralysis; scoliosis

\section{Introduction}

One of the most feared complications of the treatment of scoliosis today is paralysis. This concentrated the minds of surgeons who set up a research society to monitor the complication. In 1975, they reported an incidence of paralysis of $0.72 \%$ in a sample of 7885 patients. ${ }^{1}$ There were many causes but an iatrogenic and preventable cause was the excessive traction on the spinal column with transmitted force on the spinal cord and the nerve roots when the spine had been destabilized by cutting the ligaments. Paralysis also resulted when forcible traction was applied by means of a halotraction even without dividing the ligaments.

In France, the problem had been recognized since 1820 when surgeons carried out traction of the spinal column to correct spinal deformity using powerful mechanical means, leading to paralysis. Disputes ensued, the Royal Academy of Medicine was involved and various proponents were discredited. The purpose of this paper is to recall this event of history as it is of contemporary interest.

\section{Europe}

From the seventeenth century onwards, there was much interest in spinal deformity throughout Europe. There are accounts by Antonius Nuck (1650-1692), Jean-André Venel (1740-1791) and Johann Georg Heine (1770-1838) of mechanical correction of the deformity.

Correspondence: Dr JR Silver, 8 High Street, Wendover, Buckinghamshire HP22 6EA, UK.

E-mail: jrussellsilver@btconnect.com

Received 12 December 2007; revised 19 August 2008; accepted 10 September 2008; published online 7 April 2009
Nuck, from Holland, used a head suspension appliance called the torques. Venel, who founded an institute in Orbe, Switzerland, treated patients with two different appliances, an extension bed at night, eliminating gravity in the horizontal position and a corset in the day. He kept records of his cases using drawings and 'before' and 'after' casts. In Würzburg, Heine, an orthopaedic mechanic founded the first orthopaedic institute in Germany in 1816, where scoliosis and spinal curvature patients were treated using a bed adapted from Venel's extension bed, the Würzburg bed that involved springs and an adjustable inclined plane. ${ }^{2}$

\section{France}

Francois Guillaume Levacher de la Feutrie (1732-1816) introduced the first mechanical bed in France, in 1764 when he presented it to the Académie Royale de Chirurgie de Paris (the Académie Royale de Chirurgie was founded in 1731 but dissolved in 1793 as a result of the French Revolution. It was revived in 1843 as Société de Chirurgie de Paris. In 1935 it became Académie Nationale de Chirurgie). ${ }^{3}$ The machine was designed to 'push on the bumps' with a view to cure rakitis (rickets). It was only used on children (with soft malleable bones), and intermittently, for a maximum period of 2 weeks at a time. Levacher's machinery did not exert traction on both extremities of the body, the pressure exerted was gentle and with no adverse effect (Figures 1 and 2).

Charles Gabriel Pravaz (1791-1853) thought scoliosis was due to unequal growth or activity. He criticized the Würzburg bed for being horizontal and claimed its use was not accredited by the medical authorities. He designed 


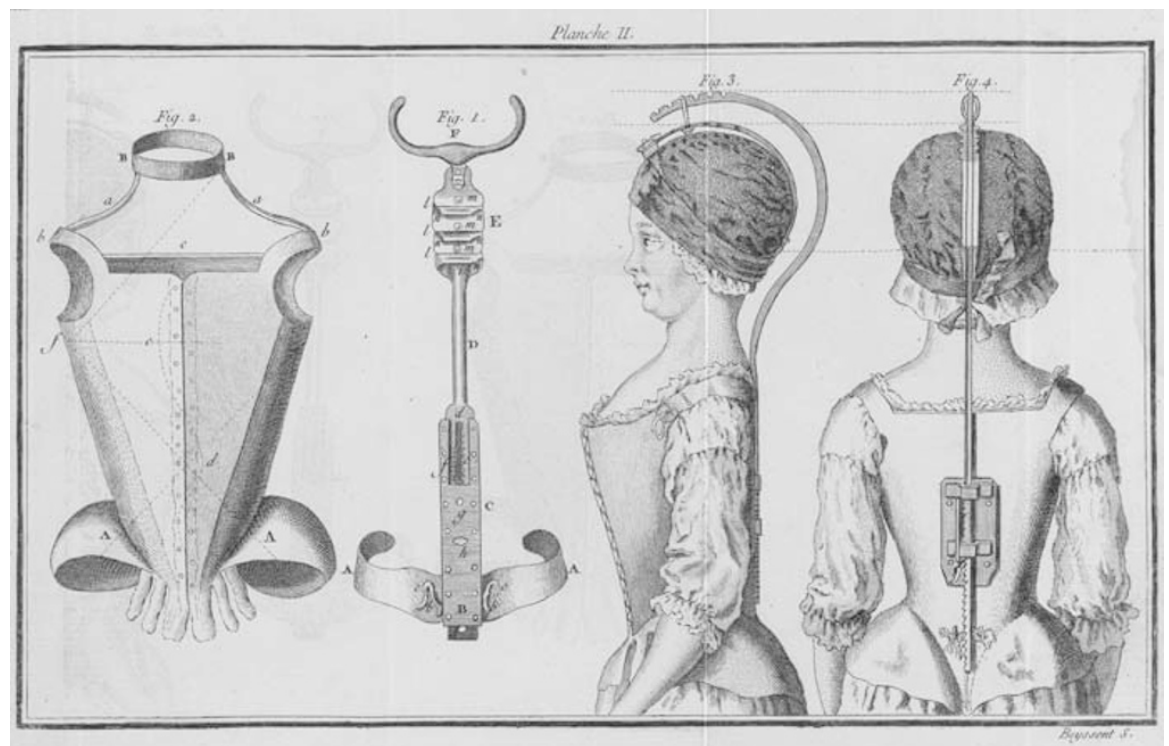

Figure 1 Minerva jacket by Levacher. Although the spine is held in a corrected position, there is no traction exerted on the spine. ${ }^{3}$

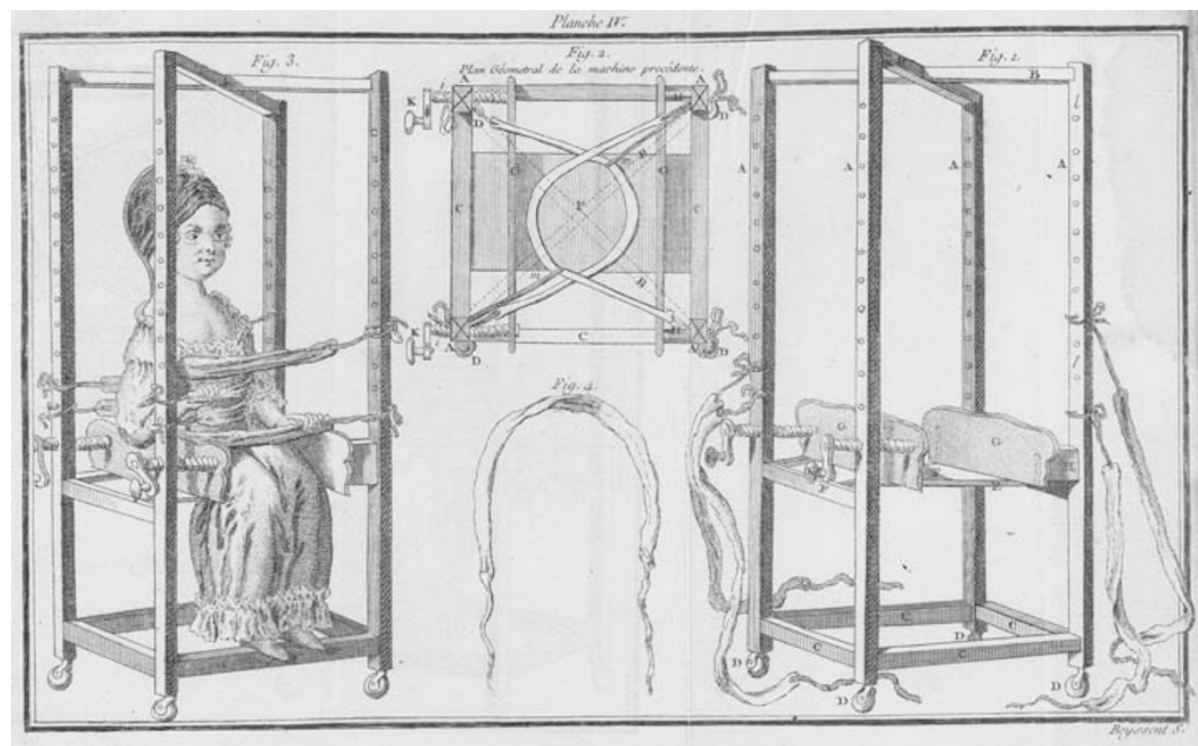

Figure 2 Extension chair for scoliosis by Levacher. Pressure is exerted on the convexities of the deformity but no traction is applied to the spine. ${ }^{3}$

extension equipment allowing patients to remain in the upright position (la balançoire orthopédique), and believed it essential for the patient to be able to adjust the traction himself. Pravaz used gentle fixation for short periods of no more than $2 \mathrm{~h}$ a day with no ill effects. Patients were not submitted to any more traction than they could bear and suffered no harm ${ }^{4}$ (Figure 3).

\section{Forced extension}

Because most intermittent methods were ineffective, the use of machinery fell into disuse in the first quarter of the nineteenth century. The situation changed dramatically in the 1820s when Charles-Auguste Maisonabe (1779-1851) introduced his mechanical bed. ${ }^{5}$ Unlike the much vaunted Würzburg spring bed, Maisonabe's bed was based on the use of weights attached to straps or ropes tied to the patient's pelvis and head, and very strong traction was applied. The bed also featured a scale/dial that was designed to show how far the weights had moved and thereby measure the force applied. The problem identified by Maisonabe himself was that the resistance of the spinal column could not be measured and therefore it was very difficult to assess the amount of weight needed to redress it. He suggested pulling the head manually to gauge the weights needed for each patient and to urge on the side of caution. The tension was increased by shortening the straps or ropes (Figure 4). 


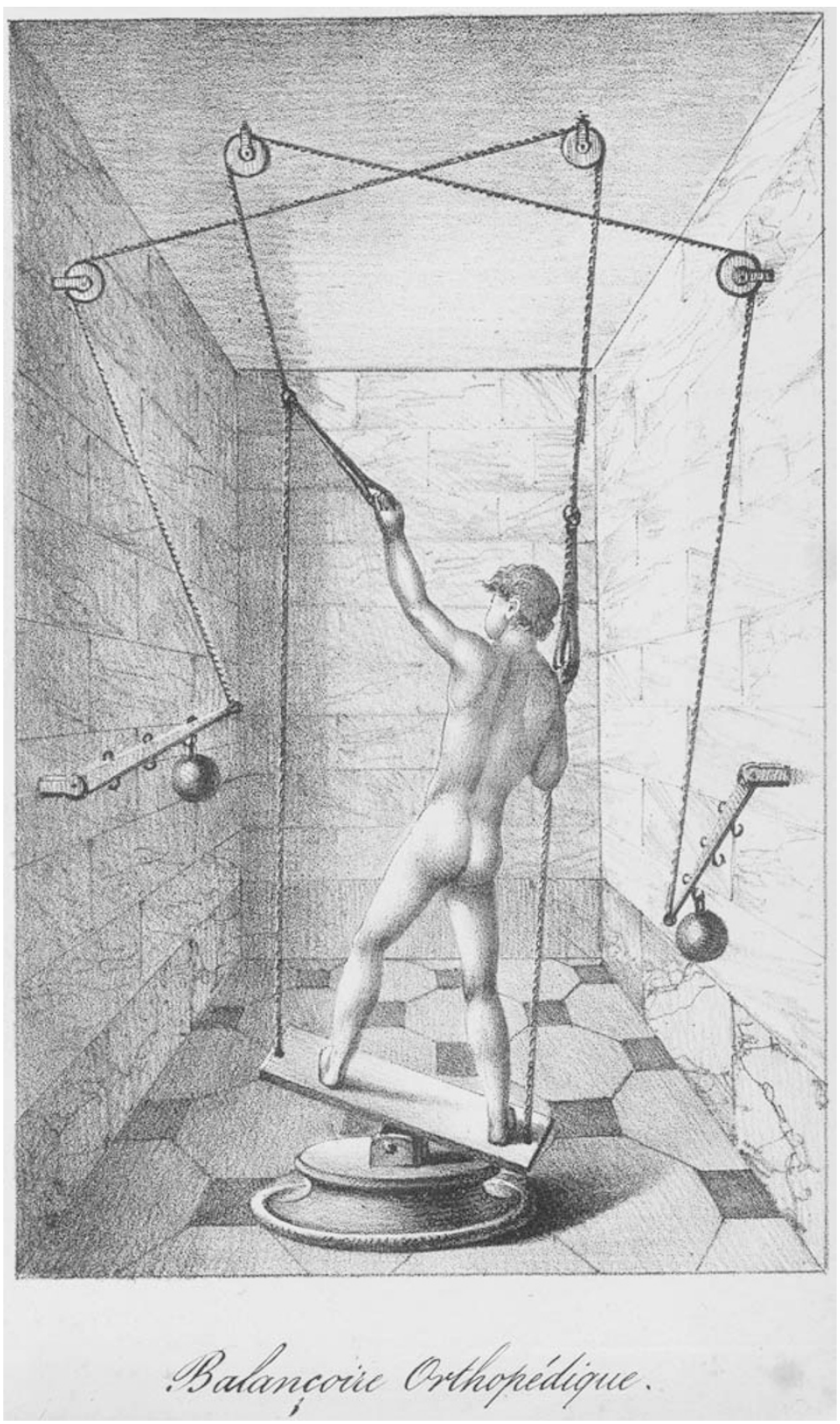

Figure 3 Balançoire orthopédique by Pravaz. Gentle fixation is applied for short periods. The patient controls the appliance and the forces exerted on their body through their limbs. No force is applied directly to the spine. ${ }^{4}$

Although Maisonabe never disputed the dangers of forceful extension, he believed that given the right precautions, extension beds could produce great benefits.

He was not unique in using forceful extension, Guillaume Jalade Lafond (birth 1805) also recognized the importance of constant traction and introduced a bed that did not rely on springs thereby allowing him to obtain a permanent extension force with an oscillary system to release the tension if required. ${ }^{6}$ Jalade Lafond's bed was strongly criticized by Maisonabe as too complicated and too expensive.
Maisonabe's empirical methods created a gradual increase of tension that led to paralysis in several cases.

The information available is too sparse to fully delineate the types of paralysis described in the above case histories. Knowledge of neurology in the eighteenth and nineteenth century was limited and few post mortems were performed. Nevertheless, there is a clear causal temporal relationship between the use of mechanical beds, traction and the development of paralysis. There was spinal cord involvement as in the cases of Dr Huet and M La Chaise. ${ }^{7}$ The progressive involvement of the shoulder and then the brain would point 


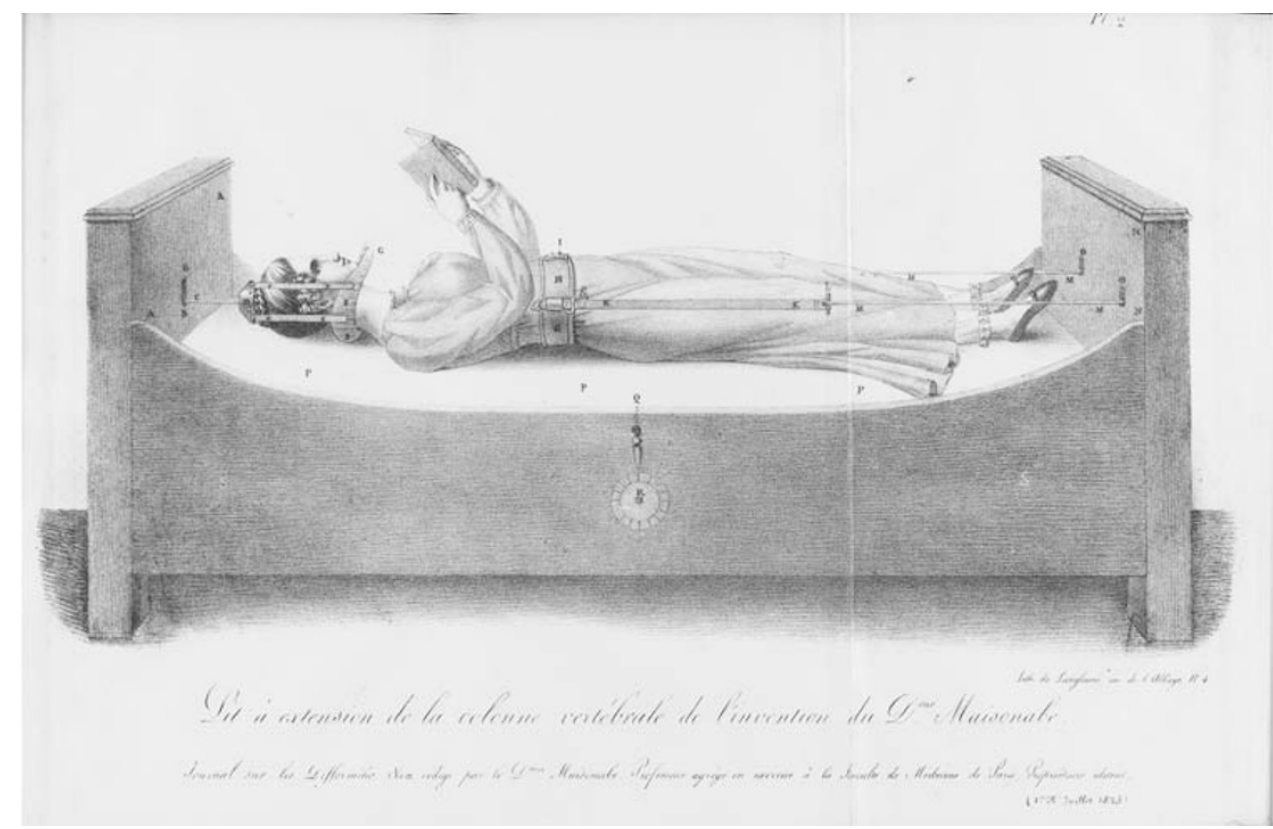

Figure 4 Extension bed by Maisonabe. In contrast to previous equipment, this extension bed exerts forceful traction directly on the spine. ${ }^{5}$

initially to a lower motor neuron lesion of the brachial plexus. The involvement of the brain is open to speculation.

Levacher's case $^{3}$ which is not specifically described is particularly interesting.

'Mais si ces ligaments se relachent, ne pourront-ils pas se relacher assez pour permettre la luxation de l'apophyse odontoide, ou du moins un commencement de luxation, capable, en gênant l'action de la moelle épinière, de causer la mort sur le champs? N'est ce pas ainsi que quelques fois on l'a vu arriver à certains enfants à qui, comme on dit, on faisait voir leur grand-père? Que leur faisait-on autre chose qu'étendre le col en tirant la tête, par le moyen du poids du corps, de la manière que le fait la machine en question?'

'But if these ligaments loosen, won't they loosen sufficiently to allow a luxation of the odontoîd peg, or at least the beginnings of a luxation, and by hindering the mobility of the spinal cord, this could result in instant death? Isn't it how we have sometimes seen with some children to whom as commonly known, we showed them their grandfather? What were we doing to them other than stretch the neck by pulling on the head, with the weight of the body, in a similar action to the apparatus we are talking about?'

We had difficulty in interpreting the meaning of the saying

'...on faisait voir leur grand-père.'

Sir Charles Bell refers to it and explains that it is swinging the child by the head and in English parlance was described as '...showing them London' leading to atlanto-axial dislocation. ${ }^{8}$

\section{The controversies}

Controversy resulted and many doctors were strongly opposed to the use of extension beds especially La Chaise who repeatedly warned against the dangers and risks of such methods, accusing the protagonists of self-interest and poor physiological knowledge (see Table 1). He believed that extension beds imposed a similar force on the whole of the spinal column, acting on the nerves and distending the spinal cord.

'How can it be distended with no risk to its natural structure and especially the surrounding envelop which is light and irritable and such delicate tissue with such an important function.'

In his account of 1828, La Chaise accused Maisonabe's extension beds of causing:

'Ulceration of the chin, the jaw and paralysis of the lower limbs. ${ }^{7}$

Apart from specific descriptions given above, it is quite clear that then and now, doctors tend not to report their fatalities or disasters (they bury their mistakes) as there are many allusions to more fatalities in the literature and this was of such concern at the time that the whole matter was referred to the Academy to arbitrate.

\section{The Royal Academy arbitrates}

The disputes reached the Académie Royale de Medecine (the Académie Royale de Médecine was founded in 1820 as the successor of both the Académie Royale de Chirurgie and the Société Royale de Médecine) and they were asked to arbitrate on the virtues and safety of the equipment. They sent Mr Béclard to assess Maisonabe's bed and methods but the 


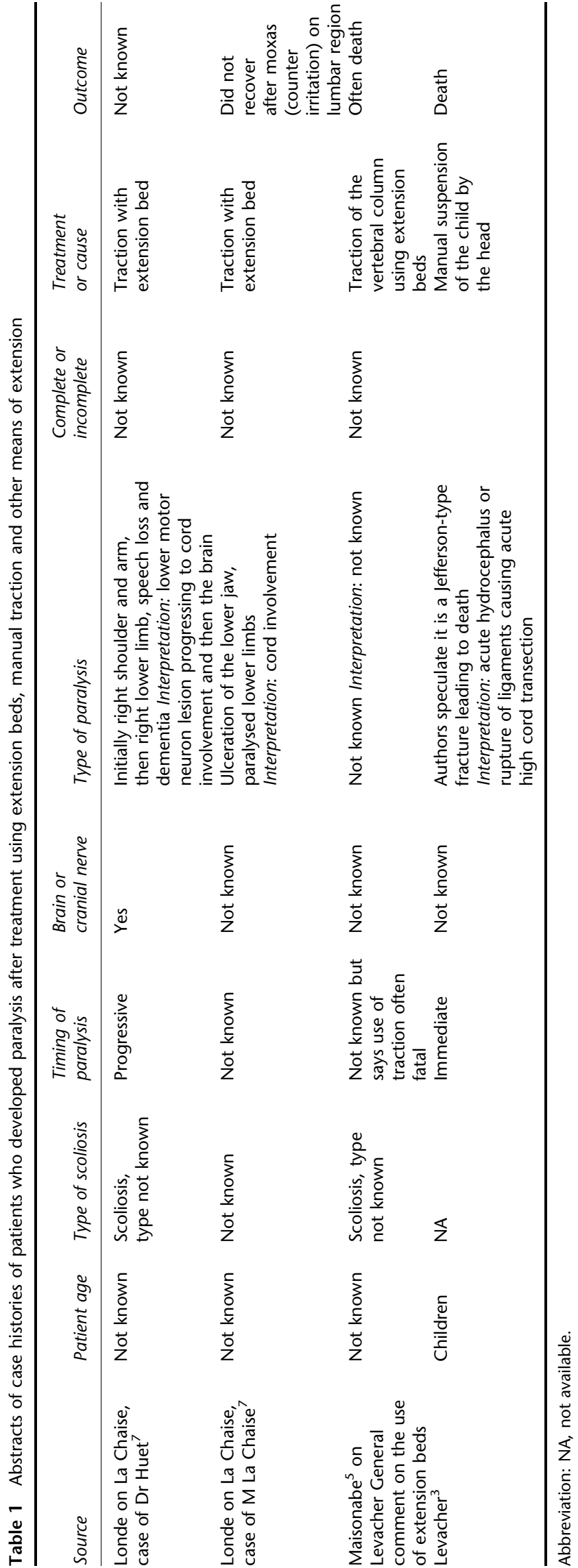

Academy was unable to issue a definitive statement. Nevertheless, Maisonabe replied to La Chaise's criticism by saying that the Academy made a favourable judgement of his bed saying that:

'It should not cause the accidents that other equipment can cause as it is well built. Used by experienced operators, it can have great benefits. ${ }^{5}$

Repeated discussions ensued but the Academy came to no conclusion. Maisonabe seemed to have lost the argument and been discredited.

In 1837, Maisonabe fled the country for Moldavia, his clinic shut down and his methods were abandoned. He returned years later a broken and lonely man. ${ }^{9,10}$

The dangers of traction on the spinal cord were clearly well recognized in France and this method of treatment was discouraged and traction fell into disuse in France.

\section{England}

The pathology of scoliosis was unknown but it was recognized that it could be caused by scrofulous caries, by disease of the spine, by rickets as well as lateral curvature. In contrast to France, in England, the treatment was largely conservative with John Shaw (1792-1827), ${ }^{11}$ Sir Charles Bell (1774-1842), ${ }^{12,13}$ Edward Harrison (1766-1838), ${ }^{14}$ George N Epps (1815-1874) ${ }^{15}$ and Robert Chessher (1750-1831) treating patients by a variety of methods including immobilization with corsets and plaster of Paris, the use of inclined beds, exercise, light traction by means of the Chessher collar and the exertion of gentle pressure on the deformity. Sir Charles Bell was aware of the dangers of manipulating a scrofulous spine and actively opposed mechanical correction. Overall, management in England was conservative without recourse to mechanical traction. ${ }^{16}$

In 1912, Tubby $^{17}$ reviewed the treatment in a comprehensive two-volume work devoting 150 pages to scoliosis or lateral curvature of the spine. He was aware that appreciable correction of the spine could be obtained by stretching. He was opposed to this both on theoretical and practical grounds and had no experience of open operation on the spine. There was no mention at all of paralysis being a complication of this form of treatment. In 1917, Albee ${ }^{18}$ described the procedure of open correction of the spine. Attempts were made to correct deformity of the spine by Risser in 1931 and Hibbs but during the 1930s and 1940s, treatment by fusion fell into disrepute because of the many failures. The results are reviewed by $\mathrm{H} \mathrm{Moe}^{19}$ but in the early stages there were no accounts of paralysis occurring as a result of treatment. Before 1950, there were few reports of neurological problems relating to scoliosis surgery. Few operations were being carried out, available techniques were limited and spinal fusion was carried out without powerful traction devices. Correction was accompanied by casts that were largely ineffectual and very uncomfortable.

In 1958, Risser and Norquist ${ }^{20}$ reported cases of paraplegia following posterior spinal fusion. It was not until 1960 that the introduction of powerful stretching devices both internal and external, that is, Harrington rods and halofemoral 
traction that paralysis began to be reported. The first records of paralysis due to excessive traction in the Anglo-Saxon literature date from 1970, when Robert Roaf (1913-2007) and Moe referred to it in their textbooks ${ }^{21,19}$ followed by Ransford and Brieg. ${ }^{22,23}$

Ransford and Manning ${ }^{22}$ described 118 patients placed in the halopelvic device, there were 6 with abducens palsies, 5 with hypoglossal palsies, 2 with glossopharyngeal palsies, 6 with brachial plexus palsies, 4 with sciatic palsies and 2 with paraplegia, 1 permanent (diastematomyelia) and 1 recovering.

Wilkins and MacEwen ${ }^{24}$ reported on 59 patients undergoing halofemoral traction. Seven patients were in halopelvic and four in halo casts. Six had cranial nerve dysfunction, the sixth cranial nerve being the most frequently involved. Also noted was the combined 9th, 10th and 12th cranial nerve palsy with difficulty in speech, swallowing and respiration. All six patients had prompt relief of their symptoms by release of the traction. In 1966, the Scoliosis Research Society was founded to assess the morbidity of these procedures. 87 patients had neurological complications out of a total of 7885 patients after scoliosis surgery. There seemed to be two major causes:

- Traction on the long cranial nerves,

- Traction on the spinal cord causing paralysis.

Brieg has described the ill effects of traction on nervous tissue and his views have received universal recognition. ${ }^{23}$ One of the most recent studies has shown that forced traction by flexion of the head during ENT procedures can also cause tetraplegia. $^{25}$

\section{Conclusion}

The ill effects of forceful mechanical correction of scoliosis were well recognized in France in the nineteenth century. In England, the methods used by Shaw and his contemporaries were much gentler and the problem of paralysis was not encountered. It was only when great forces were exerted by the use of the halofemoral traction and Harrington rods in the 1970s that this complication was encountered and its cause was recognized.

We endeavoured to show that the danger of using forceful traction on the spinal column in the correction of spinal deformity was described in France 150 years ago but this dangerous practice was not recognized in other countries until the 1970 s.

\section{Acknowledgements}

We are grateful to the Wellcome Library's Image Department for permission to reproduce the illustrations.

\section{References}

1 MacEwen DG, Bunnell WP, Sriram K. Acute neurological complications in the treatment of scoliosis. A report of the Scoliosis Research Society. J Bone Joint Surg Am 1975; 57-A: 404-408.

2 Le Vay D. The History of Orthopaedics. The Parthenon Publishing Group: New Jersey, 1990 Chapter 3, National HistoriesGermany, pp 179-219; Chapter 4, National Histories-France, pp 221-279; Chapter 7, National Histories-The Netherlands, pp 305-311.

3 Levacher de la Feutrie Traité du Rakitis. Paris 1772.

4 Pravaz C-G Méthode nouvelle pour le traitement des déviations de la colonne vértébrale. Paris 1827.

5 Maisonabe CA. Journal Clinique sur les difformités et sur la mécanique et les instruments employés par la chirurgie en France, Paris 1825.

6 Jalade-Lafond G. Rechèrches pratiques sur les principales difformités du corps humain et sur les moyens d'y remédier, Paris 1827.

7 La Chaise M. Nouvelles preuves du danger des lits mécaniques, et des avantages de la gymnastique dans le traitment des difformités de la taille. In: C Londe Archives Générales de Médecine. Béchet Jeune: Paris, 1828 6ème Année, TOME XVI, pp 646-648.

8 Bell C. Clinical lecture on diseases of the spine in the London Medicale Gazette. 1829, 327-333.

9 Izac R. Du Rouergue en Moldavie notes sur Charles Maisonabe. In: Histoire des Sciences Médicales. Tome XII, No 1 1978; (1779-1851): 451-458.

10 Dumaitre P. Pugilat à la Faculté de médecine de Paris: Dupuytren contre Maisonabe (1829). In: Histoire des Sciences Médicales, Tome XII, No 1 1978, 61-67.

11 Shaw J. On the Nature and Treatment of the Distortions to which the Spine and the Bones of the Chest are Subject. Longman Hurst Rees Orme Brown and Green: London, 1823, pp 92-97.

12 Bell C. Clinical lecture on distortion of the spine. London Medical Gazette 1835/1836; 17: 231-236.

13 Bell C. Clinical lecture on distortion of the spine. London Medical Gazette 1829/1830, 232-235.

14 Harrison E. Pathological and Practical Observations on Spinal Disease Illustrated with Cases and Engravings, also an Enquiry into The Origin of Distorted Limbs. Thomas and George Underwood: London, 1827 Chapter 2, pp 31-63.

15 Epps GN. Spinal Curvature, its Theory; its Cure. Sherwood: London, 1849.

16 Le Vay D. The History of Orthopaedics. Parthenon Publishing Group: New Jersey, 1990 Chapter 2, National Histories-Great Britain, pp 63-177.

17 Tubby AH. Deformities Including of the Bones and Joints. Macmillan: London, 1912 Vol I and II.

18 Albee FH. Bone-Graft Surgery. WB Saunders: Philadelphia, London, 1917.

19 Lonstein JE, Bradford DS, Winter RB, Ogilvie J. Moe's Textbook of Scoliosis and other Spinal Deformities, 2nd edn WB Saunders: Philadelphia, 1987 Chapter 21, pp 465-490.

20 Risser JC, Norquist DM. A follow up study of the treatment of scoliosis. J Bone Joint Surg Am 1958; 40-A: 555-569.

21 Roaf R. Spinal Deformities, 2nd edn. Pitman Medical Ltd: Tunbridge Wells, 1980 Chapter 7, pp 109-209.

22 Ransford AO, Manning CF. Complications of halo-pelvic distraction for scoliosis. J Bone Joint Surg Am 1975; 57-B: 137.

23 Brieg A. Adverse Mechanical Tension in the Central Nervous System. Almqvist and Wiksell International: Stockholm, Sweden, 1978.

24 Wilkins C, MacEwen GD. Halo-traction affecting cranial nerves. J Bone Joint Surg Am 1974; 56-A: 1540.

25 Silver JR. Paraplegia as a result of tracheal resection in a 17-yearold male. Spinal Cord 2007; 45: 576-578. 